Brit. J. industr. Med., 1950, 7, 17-26.

\title{
OBSERVATIONS ON THE WORKING ABILITY OF BANTU MINEWORKERS WITH REFERENCE TO ACCLIMATIZATION TO HOT HUMID CONDITIONS*
}

\author{
BY \\ J. S. WEINER \\ From the Medical Research Council Climatic and Working \\ Efficiency Unit, Oxford
}

\section{Introduction}

The observations reported in this paper were made at two deep working levels of the City Deep mine, Johannesburg, in the period August 30 to September 10,1948. The subjects of the test were a group of eight experienced (' acclimatized') and a second group of eight completely inexperienced Bantu workers. They were required to perform a standardized task in hot humid conditions. The main interest of the investigation derives from the fact that the routine used in the working place was identical with that used in many tests on Europeans, in varying states of acclimatization, by the Medical Research Council's Climatic Units at London and Oxford, and that both experienced and novice workers were tested. The results of the Bantu mineworkers may therefore be considered in the light of conclusions accepted for Europeans tested and acclimatized in experimental hot rooms in temperate regions.

A second point of interest lies in certain peculiarities inherent in mining conditions which became apparent in these tests, and which must be taken into account in appraising the results. It may be added that the present investigation, while exploratory in character, represents perhaps the nearest approach so far available to a direct comparison of the ' heat tolerance ' of European and non-European working subjects. The comparison by Robinson and others (1941) of the exercise capacity of Negroes and Europeans was not standardized as regards thermal conditions. The data for Indian mineworkers (Caplan and Lindsay, 1946), for Dreosti's large series of Bantu mineworkers (1935), and for Ladell's West African mineworkers (1948) cannot readily be compared with the fairly extensive available data on British and American subjects, largely

- Substance of a paper delivered at the Fourth Empire Mining and Metallurgical Congress held in Great Britain in July, 1949. because the energy output of the work performed in most cases is not known or standardized.

\section{Experimental}

All the tests except one were carried out at a drybulb of $90^{\circ} \mathrm{F}$., wet-bulb $89^{\circ} \mathrm{F}$., in a drive on the 31st level, with a through draught of air of about $165 \mathrm{ft}$./min. This place (Fig. 1) was chosen because it was relatively easily accessible from the surface, and the conditions were such that after a few days most recruits could be expected to complete the routine without collapse. While dry-bulb, wet-bulb, and globe thermometer temperature readings were remarkably stable along this drive during the tests from day to day, the air speed, owing to unforeseen circumstances, varied on the three days on which the ' acclimatized' group were tested. However, the speed remained steady during the tests on the novice group. In addition this group carried out the routine on the surface in cool conditions on the Saturday and Monday preceding the first run in the heat on the Tuesday.

The acclimatized group also carried out one test in a dead end on the 35th level (Fig. 1, overleaf). The conditions were more severe here, since there was no forced air movement. The average temperature increase over the length of drive used for the test was from $92.2^{\circ} \mathrm{F}$. dry-bulb, $90.4^{\circ} \mathrm{F}$. wet-bulb at the cooler end to $93 \cdot 3^{\circ} \mathrm{F}$. dry-bulb, $92 \cdot 7^{\circ} \mathrm{F}$. wet-bulb at the hotter end. The subjects were switched round during the test so that each man spent an equivalent period of work and rest in the hotter and in the cooler parts of the drive. The average conditions over the whole period for this working place were $92 \cdot 7^{\circ} \mathrm{F}$. dry-bulb, $91 \cdot 3^{\circ} \mathrm{F}$. wet-bulb. In the period of nine days between the three previous runs and this more strenuous test these subjects went back to ordinary work at the stope at a drybulb temperature of $90^{\circ} \mathrm{F}$. and a wet-bulb of $88^{\circ} \mathrm{F}$., and on the day immediately preceding the test on 
FIG. IC. (7.000 FT. BELOW COLLAR)

FIG. IB. (6.445 FT. BELOW COLLAR)
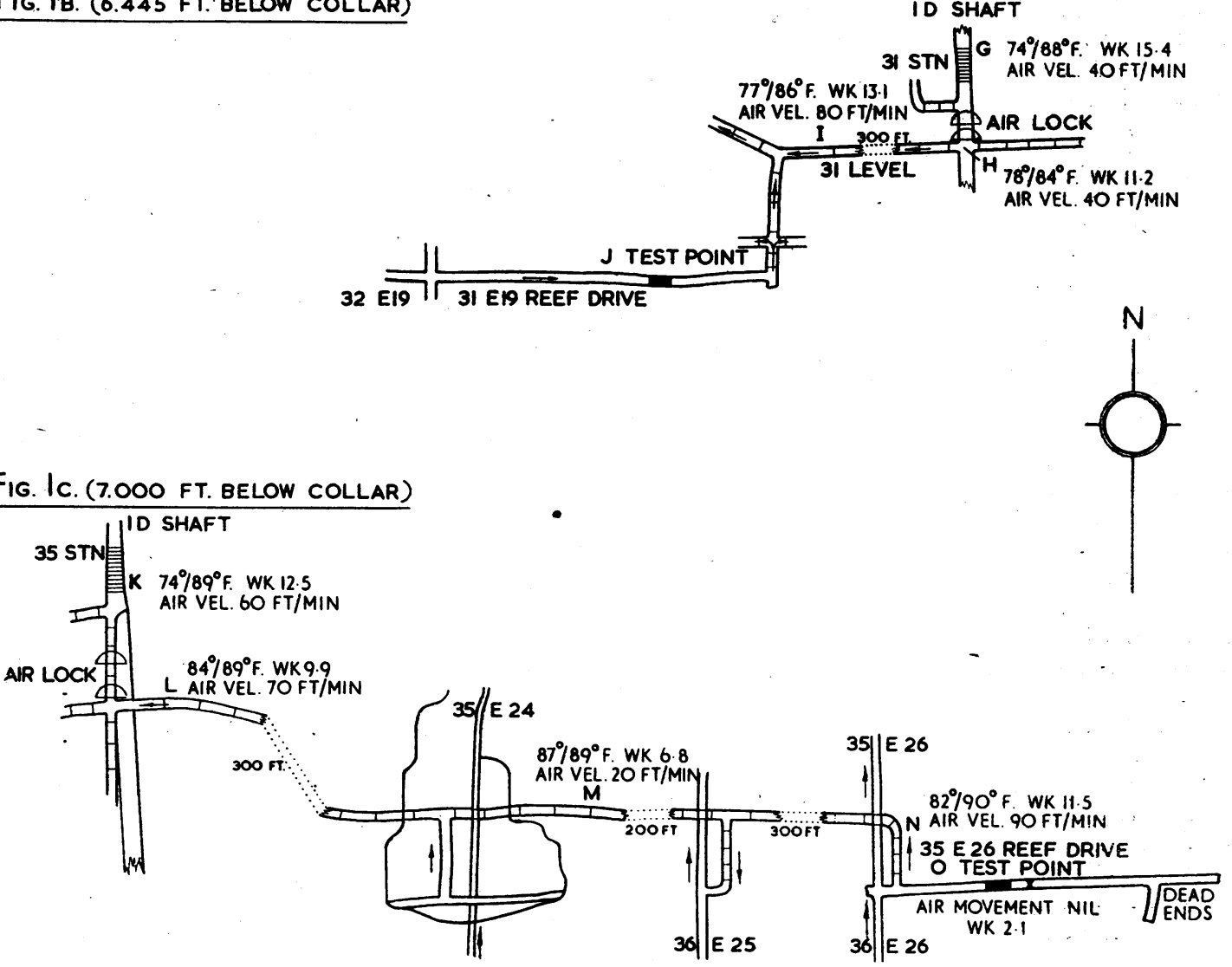

SCALE 1:2000

100 i 100 $200 \quad 300.400$

Fra. 1.-Plan of sections of No. 5 shaft to show route and environmental conditions traversed on way to test points:

1(a) Route from vertical shaft 5 to incline shaft "ID."

1(b) Route to test point on Level 31.

1(c) Route to test point on Level 35. 
the 35th level, they performed the stepclimbing routine at level 31 .

Dry- and wet-bulb temperatures were taken with a sling psychrometer: Globe thermometer readings were on the average $0.5^{\circ} \mathrm{F}$. above dry-bulb temperature. Air movements were measured at shoulder level at the three points along the drive during each period of work and in the long rest period. A hightemperature silvered dry-bulb Kata thermometer $\left(150^{\circ}\right.$ to $145^{\circ} \mathrm{F}$.) was used. The daily routine was as follows :-

0630 .. .. Reported to Native Supervisor, No. 5 Shaft.

0645-0710 .. Weighed in on surface; pulses and temperatures taken.

0715 .. . . Proceeded underground.

0720-0730 .. Walked from 26 Station, No. 5 Shaft, to 26 Station, 1D Incline Shaft, along flat haulage. (See Fig. 1(a) for route and thermal conditions.)

0745 .. . . Lowered to 31 Station or 35 Station, 1D Shaft.

0800-0815 .. Walked on to test point along flat foot-wall drive. (Fig. 1(b) shows route and temperature conditions on 31st level to test point; Fig. 1(c) route and conditions on 35th level to test point.)

0815-0830 .. Weighed in.

0830 .. . . . Started stepclimbing routine.

The temperature conditions and distances are indicated in Fig. 1(a), (b), and (c)."

The experimental routine was that used on European subjects (M.R.C. Climatic Unit, 1946).

0-10 mins. Subjects weighed nude. Shorts and plimsolls put on.

10-40 mins. Stepclimbing on and off a 1-ft. stool 12 times per minute.

40-70 mins. Sitting.

70-100 mins. Stepclimbing as before.

100-130 mins. Sitting.

130-160 mins. Stepclimbing as before.

160-220 mins. Sitting.

220-240 mins. Stepclimbing as before.

240 mins. Subjects weighed nude.
The eight subjects of the experienced group had had 3 to 6 months of underground service. Their working activities during the month preceding these tests are shown in Table 1.

The novices, six of whom came from Nyasaland, one from Bechuanaland, and one from Tanganyika, had all completed 21 days surface " training" to get them used to wearing boots, to improve their nutritional condition, and to teach them mining work in the surface school stope. None had ever been underground before these tests.

The observations made were of pulse rates in sitting and standing positions, and rectal temperatures, before and after each bout of work. The thermometer was left in 5 to 8 mins. After explanation and demonstration the subjects showed no objection whatever to having rectal temperatures taken repeatedly. With experience, half of the men preferred to take the temperature themselves. That the men would co-operate to this extent was only realized after the first few days' test on the experienced group. All rectal temperatures were checked by an independent observer; the last reading was checked on the surface. Weighings (in the nude) had perforce to be done on a platform scale which could be read to $1 \mathrm{oz}$. Water for drinking was allowed after each work period and the amount measured. Urine passed was measured.

The clothing worn consisted of shorts and canvas plimsolls as in the European experiments.

\section{Results}

The main findings of the various test runs are summarized as averages in Table 2 . This shows pulse rates and rectal temperatures, before the start of the work routine and after completion of the 3rd and 4th bouts of work, the total sweat loss.

\section{Subjects Before the Test RuN}

(1) A fact to be noted from Table 2 is that both groups recorded the highest rectal temperatures on the first day of each of the three-day runs. This is true of the temperature taken on the surface, as well

TABLE 1

WORKING PLACE DURING AUGUST, 1948, OF EIGHT EXPERIENCED WORKERS

\begin{tabular}{c|c|c|c|c|c}
\hline Mine numbers & Tribe or locality & Place & Job & W.B./D.B. ${ }^{\circ}$ F. & $\begin{array}{c}\text { Wet Kata cooling } \\
\text { power }\end{array}$ \\
\hline & Basutu & Stope & Tramming & $89 / 90$ & $7 \cdot 0$ \\
11,781 & Msutu & Stope & Tramming & $89 / 90$ & $7 \cdot 0$ \\
11,042 & East Coast & Stope & Lashing & $89 / 90$ & $6 \cdot 8$ \\
11,288 & Marosi & Shaft & Timbering & $85 / 88$ & $14 \cdot 0$ \\
11,478 & Tanganyika & Stope & Lashing & $88 / 89$ & $9 \cdot 0$ \\
10,674 & Tanganyika & Shaft & Station Boy & $74 / 88$ & $15 \cdot 4$ \\
12,408 & East Coast & Stope & Lashing & $88 / 89$ & $6 \cdot 8$ \\
11,372 & Nyasaland & Stope & Lashing & $88 / 89$ & $8 \cdot 1$ \\
\hline
\end{tabular}


TABLE 2

EFFECT OF STANDARD WORK ROUTINE ON PULSE RATE, RECTAL TEMPERATURE, AND SWEAT LOSS

Means for 8 subjects

\begin{tabular}{|c|c|c|c|c|c|c|c|c|c|c|c|}
\hline \multirow{3}{*}{ Group } & \multicolumn{3}{|c|}{ Before Work } & \multicolumn{5}{|c|}{ Effect of Work } & \multicolumn{3}{|c|}{$\begin{array}{c}\text { Underground } \\
\text { environmental } \\
\text { conditions }\end{array}$} \\
\hline & \multicolumn{2}{|c|}{ Surface } & \multirow{2}{*}{$\begin{array}{c}\begin{array}{c}\text { Under- } \\
\text { ground }\end{array} \\
\begin{array}{c}\text { Rectal } \\
\text { temp. } \\
{ }^{\circ} \mathrm{F} \text {. }\end{array}\end{array}$} & \multicolumn{2}{|c|}{$\begin{array}{l}\text { Rectal temp. } \\
{ }^{\circ} \mathrm{F} \text {. }\end{array}$} & \multicolumn{2}{|c|}{ Pulse rate } & \multirow{2}{*}{$\begin{array}{c}\text { Sweat } \\
\text { loss } \\
\text { g. }\end{array}$} & \multirow{2}{*}{ D.B. } & \multirow{2}{*}{ W.B. } & \multirow{2}{*}{$\begin{array}{c}\text { Air } \\
\text { move- } \\
\text { ment } \\
\mathrm{ft} / \mathrm{min}\end{array}$} \\
\hline & $\begin{array}{l}\text { Pulse } \\
\text { rate }\end{array}$ & $\begin{array}{c}\text { Rectal } \\
\text { temp. } \\
{ }^{\circ} \mathrm{F} \text {. }\end{array}$ & & $\begin{array}{c}\text { After } \\
\text { Work } \\
\text { (3) }\end{array}$ & $\begin{array}{c}\text { After } \\
\text { Work } \\
\text { (4) }\end{array}$ & $\begin{array}{c}\text { After } \\
\text { Work } \\
\text { (3) }\end{array}$ & $\begin{array}{l}\text { After } \\
\text { Work } \\
\text { (4) }\end{array}$ & & & & \\
\hline $\begin{array}{l}\text { NovicES } \\
\text { Level } 31 \text { : Day } 1 \\
2 \\
3\end{array}$ & $\begin{array}{r}99 \\
.82 \\
87\end{array}$ & $\begin{array}{l}99.93 \\
98.98 \\
98.95\end{array}$ & $\begin{array}{r}100 \cdot 56 \\
99 \cdot 84 \\
99 \cdot 50\end{array}$ & $\begin{array}{r}* 101 \cdot 38 \\
100 \cdot 85 \\
100 \cdot 70\end{array}$ & $\begin{array}{c}* \\
100 \cdot 60 \\
100 \cdot 51\end{array}$ & $\begin{array}{r}* 157 \\
152 \\
150\end{array}$ & $\begin{array}{l}*- \\
146 \\
148\end{array}$ & $\begin{array}{r}* 504 \\
922 \\
961\end{array}$ & $\begin{array}{l}89 \cdot 8 \\
89 \cdot 8 \\
89 \cdot 9\end{array}$ & $\begin{array}{l}89 \cdot 0 \\
88 \cdot 9 \\
88 \cdot 8\end{array}$ & $\begin{array}{l}165 \\
165 \\
165\end{array}$ \\
\hline $\begin{array}{l}\text { EXPERIENCED } \\
\text { Level 31 : Day } 1 \\
2 \\
3 \\
\text { Level } 35 \text { : Day } 4\end{array}$ & $\begin{array}{l}96 \\
79 \\
72 \\
78\end{array}$ & $\begin{array}{l}9 \overline{8 \cdot 14} \\
98 \cdot 75 \\
99 \cdot 20\end{array}$ & $\begin{array}{l}99 \cdot 94 \\
99 \cdot 38 \\
99 \cdot 24 \\
99 \cdot 54\end{array}$ & $\begin{array}{l}100 \cdot 74 \\
100 \cdot 46 \\
100 \cdot 51 \\
101 \cdot 64\end{array}$ & $\begin{array}{l}100 \cdot 40 \\
100 \cdot 14 \\
100 \cdot 26 \\
101 \cdot 12\end{array}$ & $\begin{array}{l}133 \\
124 \\
125 \\
150\end{array}$ & $\begin{array}{l}126 \\
116 \\
117 \\
152\end{array}$ & $\begin{array}{l}1,182 \\
1,321 \\
1,451 \\
1,668\end{array}$ & $\begin{array}{l}90 \cdot 2 \\
89 \cdot 9 \\
90 \cdot 1 \\
92 \cdot 7\end{array}$ & $\begin{array}{l}89 \cdot 1 \\
88 \cdot 9 \\
89 \cdot 1 \\
91 \cdot 3\end{array}$ & $\begin{array}{l}165 \\
280 \\
200 \\
\text { still }\end{array}$ \\
\hline
\end{tabular}

*Subjects withdrawn after Work (2).

as of those taken immediately before work began underground, as shown in the novice group. In the experienced group the rectal temperature was not taken on the surface on the first day since it was thought at that time expedient to take as few as were absolutely essential. Nevertheless there is little doubt that the first day's temperatures taken on the surface, like those taken before work underground, were higher than on subsequent days. Inspection of the individual results of the 16 subjects (Table 3) reveals that these elevated surface and pre-work temperatures are present with hardly an exception. From Table 2 it may be noted that the pre-work pulse rates were highest on the first day, and were higher for the novice than for the experienced group. In addition, both pre-work rectal temperatures and pulse rates of the experienced group on their recall for the more strenuous experiment at level 35 rose to levels higher than the third day at level 31 .

The 'anticipatory' elevation in pulse rate and its greater extent in the novices is not surprising, as the experiment was an event altogether out of the ordinary for these mineworkers. The novices had never been underground before. Since the daily routine never varied from day to day one must presumably regard the elevated pre-work rectal temperatures also as 'anticipatory' phenomena.

(2) Tables 2 and 3 show that the pre-work temperature level of the novice group is higher than that of the experienced group. This is manifestly so throughout each experimental series, notwithstanding that surface rectal temperatures are not available for the first day of the experienced group. These results substantiate Dreosti's conclusion (1935), based on large numbers of mouth temperature readings, that " the average initial temperature of the acclimatized native is lower than that of the unacclimatized native.' From the present results this would mean that the 'anticipatory' rise is less for the acclimatized than for the novice.

(3) A further point of interest is the finding (Table 2) in these 16 subjects, with practically no exception (Table 3), that on any particular day the journey down to the test place results in an increase in the rectal temperature. The average increase of the two groups varied somewhat on different days. There seemed to be a tendency for a reduction in the increment as the routine became known and improved. Thus on the third day in each group the increase $\left(0.50^{\circ} \mathrm{F}\right.$.) was lower than on the preceding days ; while on the last test day, when the test at the 35th level was done, the experienced group showed the smallest average increase $\left(0.34^{\circ} \mathrm{F}\right.$.) in spite of the longer journey (Fig. 1(c) ). In general these subjects arrived at the testing site with rectal temperatures $\frac{1}{2}^{\circ} \mathrm{F}$. higher than at the surface.

\section{Work Performance of the Two Groups}

The Novice Group.-On the first test day this group showed an inability to complete the routine as judged by their general condition, and high pulse 
TABLE 3

RECTAL TEMPERATURES ( ${ }^{\circ}$ F.) BEFORE STANDARD WORK TEST

\begin{tabular}{|c|c|c|c|c|c|c|c|c|c|c|c|}
\hline \multirow{2}{*}{\multicolumn{2}{|c|}{ Group }} & & \multicolumn{8}{|c|}{ Subject No. } & \multirow{2}{*}{ Mean } \\
\hline & & & 1 & 2 & 3 & 4 & 5 & 6 & 7 & 8 & \\
\hline $\begin{array}{l}\text { Novices } \\
\text { On Surface : Day }\end{array}$ & $\begin{array}{l}1 \\
2 \\
3\end{array}$ & $\begin{array}{l}\cdots \\
\cdots \\
\therefore\end{array}$ & $\begin{array}{r}100 \cdot 0 \\
99 \cdot 6 \\
99 \cdot 5\end{array}$ & $\begin{array}{l}99 \cdot 9 \\
98 \cdot 6 \\
98.6\end{array}$ & $\begin{array}{l}99 \cdot 6 \\
99 \cdot 1 \\
98 \cdot 8\end{array}$ & $\begin{array}{l}99 \cdot 9 \\
99 \cdot 0 \\
99 \cdot 5\end{array}$ & $\begin{array}{l}99 \cdot 7 \\
99 \cdot 0 \\
98 \cdot 6\end{array}$ & $\begin{array}{r}100 \cdot 5 \\
98 \cdot 7 \\
98 \cdot 7\end{array}$ & $\begin{array}{r}100 \cdot 1 \\
99 \cdot 0 \\
98 \cdot 5\end{array}$ & $\begin{array}{l}99 \cdot 7 \\
98 \cdot 8 \\
99 \cdot 4\end{array}$ & $\begin{array}{l}99.92 \\
98.97 \\
98.95\end{array}$ \\
\hline $\begin{array}{l}\text { Underground } \\
\text { Level } 31 \text { : Day }\end{array}$ & $\begin{array}{l}1 \\
2 \\
3\end{array}$ & $\begin{array}{l}\ldots \\
\ldots \\
.\end{array}$ & $\begin{array}{r}100 \cdot 6 \\
100 \cdot 1 \\
99.6\end{array}$ & $\begin{array}{r}100 \cdot 0 \\
99.5 \\
99.9\end{array}$ & $\begin{array}{r}100 \cdot 6 \\
100 \cdot 1 \\
99 \cdot 8\end{array}$ & $\begin{array}{l}101 \cdot 1 \\
100 \cdot 2 \\
100 \cdot 3\end{array}$ & $\begin{array}{r}100 \cdot 5 \\
100 \cdot 0 \\
99 \cdot 3\end{array}$ & $\begin{array}{r}100 \cdot 5 \\
99 \cdot 4 \\
99 \cdot 0\end{array}$ & $\begin{array}{r}100 \cdot 5 \\
99 \cdot 4 \\
99 \cdot 1\end{array}$ & $\begin{array}{r}100 \cdot 8 \\
100 \cdot 0 \\
99 \cdot 9\end{array}$ & $\begin{array}{r}100 \cdot 56 \\
99 \cdot 84 \\
99 \cdot 50\end{array}$ \\
\hline $\begin{array}{l}\text { EXPERIENCED } \\
\text { On Surface : Day }\end{array}$ & $\begin{array}{l}1 \\
2 \\
3 \\
4\end{array}$ & $\begin{array}{l}\cdots \\
\cdots \\
\cdots\end{array}$ & $\begin{array}{l}-\overline{98 \cdot 4} \\
99 \cdot 5 \\
98 \cdot 6\end{array}$ & $\begin{array}{l}\overline{99 \cdot 2} \\
98 \cdot 6 \\
99 \cdot 2\end{array}$ & $\begin{array}{l}-\overline{97 \cdot 0} \\
98 \cdot 0 \\
99 \cdot 4\end{array}$ & $\begin{array}{l}9 \overline{98 \cdot 9} \\
99 \cdot 4 \\
99 \cdot 7\end{array}$ & $\begin{array}{l}\overline{98 \cdot 1} \\
99 \cdot 2 \\
99 \cdot 3\end{array}$ & $\begin{array}{r}\overline{97 \cdot 9} \\
98 \cdot 5 \\
100 \cdot 3\end{array}$ & $\begin{array}{l}9 \overline{97 \cdot 6} \\
99 \cdot 4 \\
98 \cdot 3\end{array}$ & $\begin{array}{l}\overline{98 \cdot 0} \\
97 \cdot 4 \\
98 \cdot 7\end{array}$ & $\begin{array}{l}98 \cdot 14 \\
98 \cdot 75 \\
99 \cdot 19\end{array}$ \\
\hline $\begin{array}{l}\text { Underground } \\
\text { Level } 31 \text { : Day } \\
\text { Level } 35 \text { : Day }\end{array}$ & $\begin{array}{l}1 \\
2 \\
3 \\
4\end{array}$ & $\begin{array}{l}\cdots \\
\cdots \\
\cdots\end{array}$ & $\begin{array}{r}100 \cdot 0 \\
98 \cdot 6 \\
99 \cdot 1 \\
99 \cdot 0\end{array}$ & $\begin{array}{l}99 \cdot 1 \\
99 \cdot 7 \\
99 \cdot 2 \\
99 \cdot 3\end{array}$ & $\begin{array}{r}100 \cdot 6 \\
99 \cdot 0 \\
99 \cdot 3 \\
99 \cdot 9\end{array}$ & $\begin{array}{r}100 \cdot 4 \\
99 \cdot 3 \\
99 \cdot 8 \\
99 \cdot 9\end{array}$ & $\begin{array}{c}100.4 \\
99.0 \\
99.4 \\
99.5\end{array}$ & $\begin{array}{r}99 \cdot 7 \\
98 \cdot 6 \\
98 \cdot 8 \\
100 \cdot 2\end{array}$ & $\begin{array}{l}99.8 \\
98.9 \\
98.8 \\
99.5\end{array}$ & $\begin{array}{l}99.5 \\
99.2 \\
98.5 \\
99.0\end{array}$ & $\begin{array}{l}99 \cdot 94 \\
99 \cdot 37 \\
99 \cdot 24 \\
99 \cdot 54\end{array}$ \\
\hline
\end{tabular}

rate and rectal temperature. One subject (No. 6) felt dizzy and could only complete one work bout. In two other subjects (Nos. 2 and 4) the skin remained quite dry and was very hot, and the rectal temperatures went up to $101 \cdot 5^{\circ} \mathrm{F}$. and $102 \cdot 0^{\circ}$ F. after the second bout of work. The test run was terminated after the second bout of work. On the second day all the subjects except No. 4 completed the whole routine. This subject and No. 6 both sweated very little over abdomen and chest, although the forehead was moist. No. 4's rectal temperature was $101 \cdot 8^{\circ} \mathrm{F}$. after the second bout of work. On the third day all subjects completed the routine and all had moist skins, although No. 4 still seemed to sweat slowly.

Further experiments would be needed to decide whether these Bantu acclimatized more rapidly than Europeans.

From Table 2 it is clear that with repeated exposure the final and maximum body temperatures became progressively reduced, while the sweat loss increased. The pulse rate after work also declined. These findings and the improved ability to work are characteristic of the phenomena of acclimatization, as seen in experimental hot rooms in humid conditions (Dreosti, 1935 ; Weiner, 1946), and in desert conditions (Taylor and others, 1943 ; Robinson and others, 1943), as well as the tendency to sweat more and sooner at a progressively lower body temperature with repeated exposures at high temperatures (McArdle, 1944 ; Weiner, 1944). A recent experiment in this laboratory furnishes a particularly clear example of this phenomenon, as is shown in Table 4 (Weiner and van Heyningen, 1949).

The Experienced Group.-On the first day the experienced group were able to finish the whole routine. The environmental conditions on this day were comparable with those prevailing throughout the three days experiments on the recruits. Table 2 shows that the experienced group were in a more developed state of acclimatization at the beginning than were the recruits after three runs. The sweat rate is somewhat higher and the final rectal temperature about the same. The pulse rate is much lower. On subsequent days the experiments on the experienced group are complicated by the fact that air velocities were higher than on the first day. Table 2 shows that the sweat rate continued to increase on subsequent days, whereas the effect of an increased air movement in those conditions, as discussed later, is known to reduce the sweat output (M.R.C. Climatic Unit, 1946). Hence the experienced group would appear to have continued to show improvement as judged by the sweat-rate rectal-temperature criterion.

The results of the experiment at level 35 in the more strenuous environment are shown in Table 2. The subjects appeared very distressed by the still air conditions and needed much exhortation to carry on. 
TABLE 4

ACClimatization OF A EUROPEAN WORKING SUBJECT TO D.B. $114^{\circ}$ F., W.B. $85^{\circ}$ F., AIR MOVEMENT 50 FT./MIN.

\begin{tabular}{|c|c|c|c|c|c|c|c|c|c|c|}
\hline \multicolumn{5}{|c|}{ Day of Exposure } & \multirow{2}{*}{$\begin{array}{c}\begin{array}{c}\text { Sweat Loss } \\
\mathrm{kg} .\end{array} \\
\\
0.349 \\
0.897 \\
0.563 \\
1.320 \\
1.373\end{array}$} & \multirow{2}{*}{$\begin{array}{c}\begin{array}{c}\text { Duration } \\
\text { min. }\end{array} \\
\\
56 \\
108 \\
102 \\
140 \\
142\end{array}$} & \multirow{2}{*}{$\begin{array}{c}\text { Sweat Rate } \\
\text { g./min. } \\
\\
6.23 \\
8.31 \\
5.52 \\
9.43 \\
9.67\end{array}$} & \multirow{2}{*}{ 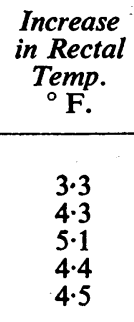 } & \multirow{2}{*}{$\begin{array}{c}\text { Max. Rectal } \\
\text { Temp. } \\
{ }^{\circ} \mathrm{F} . \\
\\
102 \cdot 3 \\
103 \cdot 1 \\
103 \cdot 3 \\
103 \cdot 2 \\
102 \cdot 7\end{array}$} & \multirow{2}{*}{$\begin{array}{c}\text { Sweat Rate, } \\
\text { Rectal Temp. } \\
\text { Increment } \\
\text { g./min. } \text { / }^{\circ} \mathrm{F} . \\
\\
1.89 \\
1.93 \\
1.08 \\
2.14 \\
2.15\end{array}$} \\
\hline $\begin{array}{r}\text { Week } \\
1 \\
2 \\
3 \\
4 \\
5\end{array}$ & $\begin{array}{l}1- \\
\cdots \\
\cdots \\
\cdots \\
\cdots\end{array}$ & $\begin{array}{l}\cdots \\
\cdots \\
\cdots \\
\cdots\end{array}$ & $\begin{array}{l} \\
\cdots \\
\cdots \\
\cdots \\
\cdots\end{array}$ & $\begin{array}{l}\ldots \\
\ldots \\
\ldots \\
\ldots\end{array}$ & & & & & & \\
\hline $\begin{array}{r}\text { Week } \\
6 \\
7 \\
8 \\
9 \\
10\end{array}$ & $\begin{array}{l}2- \\
\cdots \\
\therefore \\
\cdots \\
\cdots\end{array}$ & $\begin{array}{l}\ldots \\
\cdots \\
\ldots \\
\ldots\end{array}$ & $\begin{array}{l}\cdots \\
\cdots \\
\cdots \\
\cdots\end{array}$ & 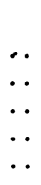 & $\begin{array}{l}1.091 \\
1.175 \\
1.705 \\
1.640 \\
1.740\end{array}$ & $\begin{array}{l}144 \\
144 \\
140 \\
140 \\
140\end{array}$ & $\begin{array}{r}7 \cdot 58 \\
8 \cdot 16 \\
12 \cdot 18 \\
11 \cdot 71 \\
12 \cdot 43\end{array}$ & $\begin{array}{l}3 \cdot 0 \\
3 \cdot 0 \\
3 \cdot 4 \\
3 \cdot 1 \\
3.9\end{array}$ & $\begin{array}{l}101 \cdot 8 \\
101 \cdot 8 \\
102 \cdot 2 \\
101 \cdot 3 \\
101 \cdot 7\end{array}$ & $\begin{array}{r}2.53 \\
2.72 \\
3.21 \\
3.78 \\
3.19\end{array}$ \\
\hline $\begin{array}{r}\text { Week } \\
11 \\
12 \\
13 \\
14 \\
15\end{array}$ & $\begin{array}{l}3- \\
\ldots \\
\ldots \\
\ldots \\
\ldots\end{array}$ & $\begin{array}{l}\cdots \\
\cdots \\
\because \\
\therefore\end{array}$ & $\begin{array}{l}\ldots \\
\cdots \\
\cdots \\
\cdots\end{array}$ & $\begin{array}{c}\ldots \\
\cdots \\
\cdots \\
\cdots\end{array}$ & $\begin{array}{l}1.625 \\
1.690 \\
1.560 \\
1.695 \\
1.660\end{array}$ & $\begin{array}{l}140 \\
148 \\
139 \\
140 \\
140\end{array}$ & $\begin{array}{l}11 \cdot 61 \\
11 \cdot 42 \\
11 \cdot 22 \\
12 \cdot 11 \\
11 \cdot 86\end{array}$ & $\begin{array}{l}3 \cdot 4 \\
3 \cdot 3 \\
2 \cdot 8 \\
3 \cdot 6 \\
2 \cdot 1\end{array}$ & $\begin{array}{l}102 \cdot 0 \\
101 \cdot 3 \\
101 \cdot 6 \\
101 \cdot 7 \\
101 \cdot 2\end{array}$ & $\begin{array}{l}3.42 \\
3.46 \\
4.07 \\
3.36 \\
5 \cdot 65\end{array}$ \\
\hline
\end{tabular}

\section{Comparison with EURopean SUbJects}

Data on the reactions of acclimatized Europeans to the routine of work used in this acclimatization are available from the records of the M.R.C. Climatic Units at Queen Square and at Oxford. Comparable tests for Europeans were done at wet-bulb temperatures of $88.0^{\circ} \mathrm{F}$., dry-bulb 90 to $92^{\circ}$, and wet-bulb $90^{\circ}$ and dry-bulb $92^{\circ}$; for the still air conditions of level 35 at wet-bulb temperature averaging $91.3^{\circ}$, some European data relating to wet-bulbs of 90,91 , and $92^{\circ} \mathrm{F}$. may be used. In addition to data from actual experiments it is possible also to interpolate from the four-hourly sweat rate nomogram (M.R.C. Climatic Unit, 1947) which covers the sweating results for a wide range of test combinations on acclimatized Europeans performing this work routine. All these sweat-rate data, actual and derived, are presented in relation to air movement in Figs. 2 and 3. (The theoretical -sweat rate from the M.R.C. nomogram at still air conditions is in excess of the actual data.) Fig. 2 shows the average results and Fig. 3 the individual results. The continuous line for Europeans (M.R.C. Climatic Unit, 1946) in Fig. 2, with which the Bantu and other European data are compared, relates to a wet-bulb temperature $1^{\circ} \mathrm{F}$. lower than that for the Bantu-i.e., the European sweat rate tends to be underestimated. However, this difference may be regarded as providing a margin of safety, since wet-bulb temperatures in the mining experiments were taken with a sling and not with an Assman psychrometer as in the European experiments. The European curve in Figs. 2 and 3 indicates that in these conditions increasing air movement decreases the sweat rate of acclimatized men. The findings in Figs. 2 and 3 may be summarized as follows :-

(i) The Bantu novices as a group are well below the European acclimatized level, even on the third repetition of the work.

(ii) The experienced Bantu are very nearly equal to the European level by the second day and certainly attain it by the third, in the experiments at high air speeds.

(iii) In still air conditions the experienced Bantu performance falls below that of the European.

The general conclusion appears to be that as regards ability to sweat, particularly in the still air environment, even the experienced Bantu are apparently not quite in the same state of acclimatization as expected from the performance of European subjects.

Attention has been drawn to that characteristic of thermal acclimatization, whereby, with repetition of exposure, sweating at a high level tends to occur at somewhat lower body temperatures. It was also noted that both Bantu groups by this criterion gave evidence of an improvement with repeated exposure. We should therefore expect from the results pre- 


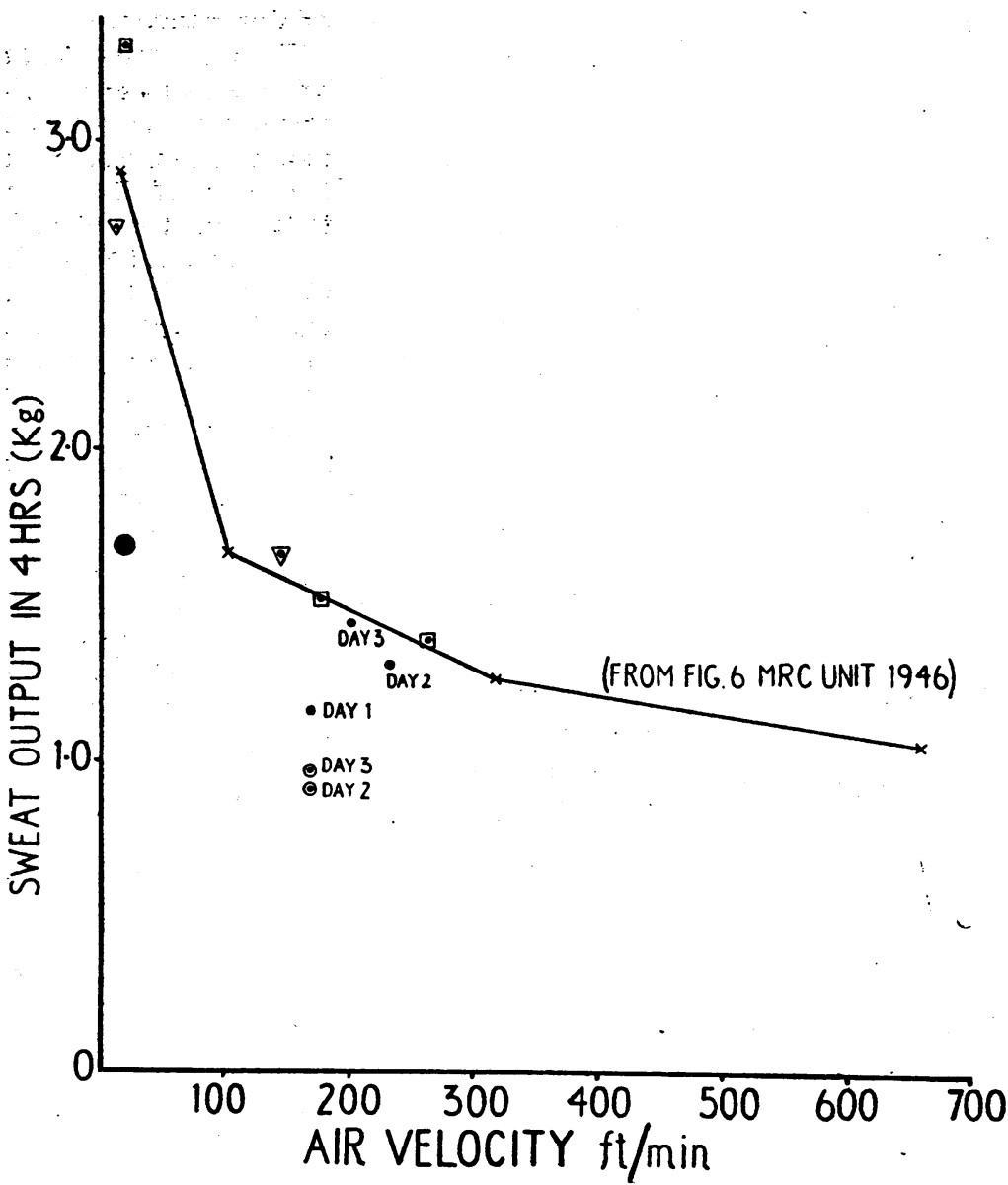

FIG. 2.-Comparison of sweat output of Bantu novices and Bantu experienced subjects with that of acclimatized Europeans in relation to air movement - average results of groups.

$$
\begin{array}{rll}
\odot & \text { Bantu novices. } \\
\bullet & \text { Bantu experienced. } \\
\nabla & \text { Europeans (Oxford). } \\
\mathrm{X} & \text { Europeans (Queen Square). } \\
\square & \text { Europeans (Queen Square Nomogram). }
\end{array}
$$

Discussion.

ACCLIMATIZATION ÁND WORK CapactTy of Bantu

The findings on the Bantu workers described raise the question of the applicability in general of conclusions based on tests on European subjects. The European subjects, in particular those of the Queen Square series (M.R.C. Climatic Unit, 1946, 1947), were kept acclimatized to the standard test, under a large variety of heat load conditions for three to four months. These men were able to perform the required four-hour routine in circumstances which entailed the loss of four and even six litres of sweat. The increased ability of the acclimatized man to sweat is associated not only with improvement in heat regulation, but in an increased capacity of the circulation to accommodate itself to the demands of blood flow of the periphery and of the working. muscles (Weiner and Wyndham, 1948). The sweating capacity of acclimatized men has a reasonable basis for adoption as an index of the response to the heat load imposed by the interaction of environmental factors - the temperature, humidity, movement of the air, radiant heat, combined with the work load and amount of clothing worn. Combinations of these factors. which have an equivalent physiological effect as judged

sented in Figs. 2 and 3 that the Bantu body temperatures and pulse rates would tend to be above those of the European. Table 5 indicates that this is so for both sets of conditions, even where European data for somewhat severer wet-bulb conditions are included in the comparison. Examination of the table also suggests that the superiority of the European is not necessarily due to a lower initial pre-work rectal temperature, since in some cases prework temperatures are fairly similar but nevertheless final temperatures are lower than in the Bantu. by the sweat output are presented on a nomogram (M.R.C. Climatic Unit, 1946). As examples of 'performance' standards, one might envisage a level of sweat output which is easily within the capacity of the majority of acclimatized men, or, again, one which represents the maximum desirable output (and this has been considered as near the four-litre level*). One may stipulate from the nomogram the

- An upper limit at this level accords well with the maximum performance of the acclimatized subjects of the investigation by 


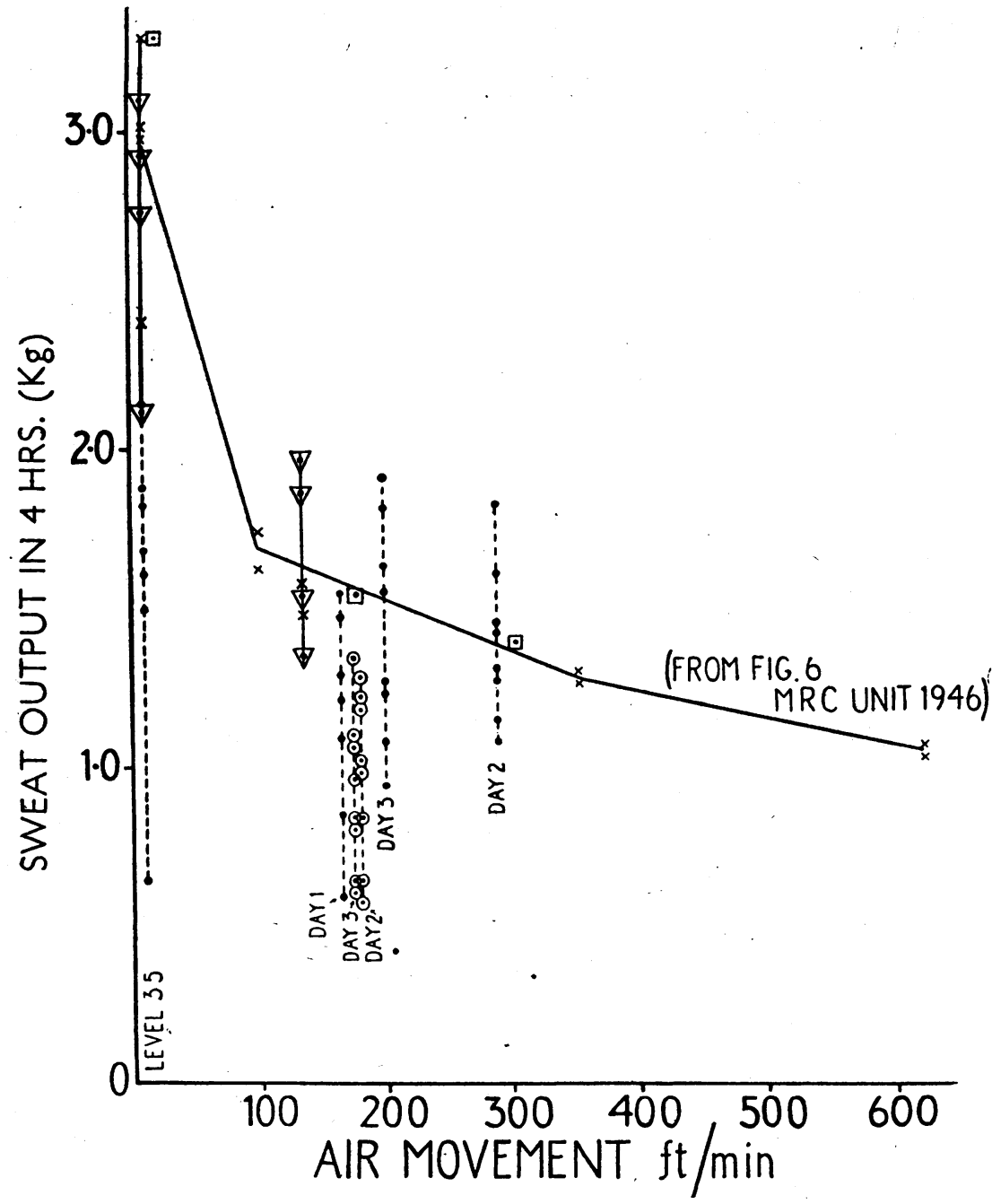

Fig. 3.-Comparison of sweat output of Bantu novices and Bantu experienced subjects with that of acclimatized Europeans in relation to air movement-individual results.

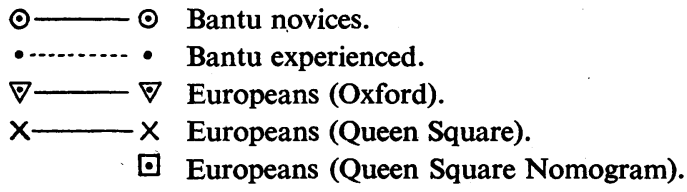

various combinations which would yield equivalent conditions of 'heat stress'. The importance in practice to mining of such 'standards' and of the assessment of equivalent conditions based on the adoption of a physiological criterion such as sweat output will be apparent, but the present results do not allow the recommendation that the available European index should be immediately adopted for mining practice.

The experienced Bantu subjects in these experiments have been tested in conditions, which, on the basis of European tests and the M.R.C. nomogram (M.R.C. Climatic Unit, 1947), would yield sweat losses of 1.5 and 2.5 to three litres over the four-hour test period. It has been seen that at both these levels the sweat output, as well as the performance judged by rectal temperature and pulse rate, falls somewhat short of the European findings, especially at the 2-5-litre level. Ladell (1948) mentions that judged by a single preliminary test West African coalminers could not work so hard in severe heat as fullyacclimatized Europeans.

The Bantu are acclimatized to mining conditions and routine (i.e., mining clothing, intensity of mining work, and range of mining environmental conditions) as well as to the extra stress of the journey to the work place. The somewhat inferior performance of the experienced Bantu might be ascribed to some or all the following differences in conditions :

(1) It may be that in mining work the overall energy output is in fact not so high as the average $110 \mathrm{Kcals} / \mathrm{m}^{2} / \mathrm{hr}$. level of the routine test or does not reach the intensity of the work done in the active $\frac{1}{2}$-hour periods $\left(180 \mathrm{Kcals} / \mathrm{m}^{2} / \mathrm{hr}\right.$.) of the four-hour routine; in other words that the Bantu are not acclimatized to this level of continuous energy output. This would imply that mining work does not entail this moderate energy expenditure, es- 
TABLe 5

COMPARISON OF BANTU AND EUROPEAN PERFORMANCE (RECTAL TEMP. AND PULSE RATE) AT HIGH TEMPERATURES

\begin{tabular}{|c|c|c|c|c|c|c|c|c|c|c|c|}
\hline & & & & & $\begin{array}{l}\text { ironme } \\
\text { onditio }\end{array}$ & & Recta & $\begin{array}{l}\text { Tempe } \\
\circ \mathrm{F} \text {. }\end{array}$ & ature & $\begin{array}{l}\text { Pulse } \\
\text { (Star }\end{array}$ & $\begin{array}{l}\text { Rate } \\
\text { ling) }\end{array}$ \\
\hline & Conditions & & $\left|\begin{array}{c}\text { No. of } \\
\text { Subjects }\end{array}\right|$ & $\begin{array}{l}\text { Dry } \\
\text { bulb, } \\
{ }^{\circ} \mathrm{F} \text {. }\end{array}$ & $\begin{array}{l}\text { Wet } \\
\text { bulb, } \\
{ }^{\circ} \mathrm{F} \text {. }\end{array}$ & $\begin{array}{l}\text { Air } \\
\text { move- } \\
\text { ment, } \\
\mathrm{ft} / \mathrm{min}\end{array}$ & $\begin{array}{l}\text { Before } \\
\text { Work }\end{array}$ & $\begin{array}{l}\text { After } \\
\text { Work } \\
3\end{array}$ & $\begin{array}{c}\text { After } \\
\text { Work } \\
4\end{array}$ & $\begin{array}{l}\text { After } \\
\text { Work } \\
3\end{array}$ & $\begin{array}{c}\text { After } \\
\text { Work } \\
4\end{array}$ \\
\hline Level & $\begin{array}{l}\text { Bantu Novices, Day } 3 \\
\text { Bantu Experienced, Day } 3 \\
\text { Europeans, Queen Square } \\
\text { Europeans, Queen Square } \\
\text { Europeans, Oxford .. }\end{array}$ & $\begin{array}{l}\cdots \\
\cdots \\
\cdots \\
\cdots\end{array}$ & $\begin{array}{l}8 \\
8 \\
2 \\
2 \\
4\end{array}$ & $\begin{array}{l}89 \cdot 9 \\
89 \cdot 9 \\
90 \cdot 2 \\
91 \cdot 3 \\
91 \cdot 2\end{array}$ & $\begin{array}{l}88 \cdot 8 \\
89 \cdot 1 \\
88 \cdot 1 \\
90 \cdot 0 \\
90 \cdot 0\end{array}$ & $\begin{array}{l}165 \\
200 \\
100 \\
135 \\
135\end{array}$ & $\begin{array}{l}99 \cdot 5 \\
99 \cdot 2 \\
99 \cdot 1 \\
98 \cdot 3 \\
99 \cdot 6\end{array}$ & $\begin{array}{l}100 \cdot 7 \\
100 \cdot 5 \\
100 \cdot 0 \\
100 \cdot 0 \\
100 \cdot 3\end{array}$ & $\begin{array}{r}100 \cdot 5 \\
100 \cdot 3 \\
99 \cdot 7 \\
99 \cdot 6 \\
99 \cdot 9\end{array}$ & $\begin{array}{l}150 \\
125 \\
110 \\
109 \\
110\end{array}$ & $\begin{array}{l}148 \\
117 \\
108 \\
111 \\
102\end{array}$ \\
\hline Level & $\begin{array}{l}\text { Bantu Experienced, Day } 4 \\
\text { Europeans, Queen Square } \\
\text { Europeans, Queen Square } \\
\text { Europeans, Oxford .. }\end{array}$ & $\begin{array}{l}\cdots \\
\ddot{*} \\
\cdots\end{array}$ & $\begin{array}{l}8 \\
2 \\
5 \\
4\end{array}$ & $\begin{array}{l}92 \cdot 7 \\
91 \cdot 1 \\
92 \cdot 8 \\
91 \cdot 4\end{array}$ & $\begin{array}{l}91 \cdot 3 \\
89 \cdot 9 \\
92 \cdot 2 \\
91 \cdot 4\end{array}$ & $\begin{array}{r}\text { still } \\
10 \\
10 \\
10\end{array}$ & $\begin{array}{l}99 \cdot 5 \\
98 \cdot 9 \\
99 \cdot 5 \\
99 \cdot 4\end{array}$ & $\begin{array}{l}101 \cdot 6 \\
100 \cdot 3 \\
100 \cdot 7 \\
101 \cdot 2\end{array}$ & $\begin{array}{l}101 \cdot 1 \\
100 \cdot 0 \\
101 \cdot 0 \\
100 \cdot 8\end{array}$ & $\begin{array}{l}150 \\
133 \\
135 \\
136\end{array}$ & $\begin{array}{l}151 \\
138 \\
144 \\
137\end{array}$ \\
\hline
\end{tabular}

pecially when high temperatures are encountered, due to rest periods and other pauses. One cannot say more about this important factor, since data on the calorie cost and mechanical efficiency of mining tasks are not ayailable.

(2) It may be that in the course of several months of mining work, though conditions of the order of the 1.5-litre sweat level are common, more severe and especially still air conditions above the threelitre level are not encountered sufficiently often or long enough to confer acclimatization to this level.

(3) In mining work the particular circumstances inherent in the routine (longer exposure, long journey to the work place, type of work, and posture during work) may militate against the acquisition of the physiological performance expected from the results of experimental hot-room tests.

(4) A racial difference may be involved.

(5) The difference in body surface area between Queen Sq. subjects (1.75 sq. m.) and the Bantu (experienced 1.65 ; novices 1.67 sq. m.) may account for the difference in sweat-output.

As already noted the reduced sweating in these experiments is associated with greater increases in pulse rate and rectal temperature than those of the Europeans. This points to a lesser state of acclimatization since the acclimatization change is that of an increased ability to sweat relative to the elevation of body temperature.

The present experiments are admittedly restricted and cannot pretend to give a full answer to the problem of the operation of a racial factor in response to heat. Particularly is this so since higher sweat levels of 4 and 5 litres did not come under investigation. In any case, it is clear that standards of performance obtained from individuals acclimatized in one set of circumstances, such as those of the Queen Square artificial hot rooms, cannot without qualification or further testing be applied to the case of mining where, in spite of severe environmental conditions, differences in the state of acclimatization as well as in race and body-size may be operative. Expected levels of performance in relation to different combinations of heat load factors, such as those available for Europeans, should be supplemented by a comprehensive series of physiological tests on Bantu, in which the level of acclimatization afforded by average mining conditions is taken as a base line.

\section{Rate of ACClimatization}

While the present experiments are too limited in scope to answer the practical questions about the value of existing methods of underground acclimatization, certain comments may be made. These experiments, like many carried out on Europeans, show that under supervision it is possible for men to do a full four hours' work at the $110 \mathrm{Kcal} / \mathrm{m}^{2} / \mathrm{hr}$. level within as short a time as three days. That is not to say that such men are as fully acclimatized as is desirable - the rectal temperatures still tend to rise unduly and the pulse rate after work is still high. The tendency to heat collapse caused by circulatory inefficiency (Weiner, 1938) and to incipient heat stroke, as suggested by a rising body temperature combined with a dry hot skin, are both still manifested within this time. Hence the need for reliable supervision in this type of régime. 
The performance by Bantu novice workers of a standardized task in hot mining conditions does not reveal any high degree of ' natural' heat tolerance.

As with the European, acclimatization is acquired with repeated exposure and after three days Bantu workers are able to complete a routine involving a heat output of $110 \mathrm{Kcals} / \mathrm{m}^{2} / \mathrm{hr}$. for four hours.

The Bantu worker with four to six months continuous experience of hot mining conditions is probably not quite in the same state of acclimatization as Europeans who have been acclimatized over several months to a variety of standard test conditions in experimental hot rooms. In the experienced Bantu the sweat rate is somewhat lower and the rectal temperature and pulse rate somewhat higher than in the case of the acclimatized European, when both groups are tested by the same procedure. This is especially so in conditions of high wet-bulb temperature and minimal air movement.

Repetition of the test brings the Bantu to the European level as regards sweating although rectal temperature still remains a trifle higher.

In evaluating these differences certain complicating factors peculiar to mining must be taken into account. The rectal temperature even in the acclimatized group shows an 'anticipatory' rise on the first day of the test. In addition the rectal temperature rises 0.5 to $0.8^{\circ} \mathrm{F}$., in the course of the journey from the surface to the working place.

In view of the restricted nature of the investigation, it would be premature to discount a racial difference : but the results stress the significance of factors in the previous history of work in hot conditions-i.e. of acclimatization.

In view of these results caution must be exercised in using standards based on results from workers acclimatized to a different routine. The need for accurate comparison of European and Bantu in the unacclimatized and acclimatized state is stressed.

\section{Summary}

A group of eight Bantu mining recruits and one of eight Bantu workers with 4 to 6 months experience were required to perform at D.B. $90^{\circ}$, W.B. $89^{\circ} \mathrm{F}$., a standardized task identical to that used previously on European subjects. Three successive experiments were done on each group. Progressive changes in sweat rate, rectal temperature, and pulse rate characteristic of acclimatization were noted in both groups. The experiments in these conditions with air movement varying from 165 to $300 \mathrm{ft}$./min., and a further single experiment in still air at D.B. $93 \cdot 3^{\circ}$, W.B. $91 \cdot 2^{\circ}$ F. on the experienced group, indicate that these experienced Bantu mine workers are not in a better state of acclimatization than Europeans artificially acclimatized to work at a $110 \mathrm{Kcals} / \mathrm{m}^{2} / \mathrm{hr}$. level. The main conclusion is that standards based on the performance of these European subjects should be applied only with caution to workers in other circumstances : i.e. Bantu mineworkers.

The author is grateful to Dr. A. J. Orenstein, Chief Medical Officer, and to Mr. F. G. Hill, Engineering Consultant to the Rand Mines Central Mining Group, for making available facilities for the investigation, and to the manager of the City Deep mine, Mr. H. W. Unwin, for placing technical assistants, equipment, and experimental subjects at his disposal. He also acknowledges gratefully the co-operation of $\mathrm{Mr}$. Barcza of the Ventilation Department of Rand Mines, Ltd., who participated in most of these tests. The main burden of the organization and execution of the experiments fell on Mr. Alistair Black, of City Deep, Ltd., who also provided the ventilating data.

\section{REFERENCES}

Caplan, A., and Lindsay, J. K. (1946). " Effect of high temperatures on efficiency in deep mines." Bull. Instn Min. Metall., Lond No, 480.

Dreosti, A. O. (1935). J. chem. Soc., S. Afr., 36, 102.

Eichna, L. W., Ashe, W. F., Jnr., Bean, W. B., and Shelley, W. B. (1945). J. industr. Hyg., $27,59$.

Ladell, W. S. S. (1948). British Journal of Industrial Medicine, 5, 16. McArdle, B. (1944). Oral communication to the Physiological Society quoted by Ladell, W. S. S. (1945). Brit. med. Bull., 3,175 .

M. R. C. Climatic Unit (1946). "The effects of air movement in severe heat." Report to Royal Naval Personnel Research Committee, R.N.P. 46/316, H.S. 152

M. R. C. Climatic Unit (1947). "The Prediction of the physiological effects of warm and Naval
194.

Robinson, S., Dill, D. B., Harmon, P. M., Hall, F. G., and Wilson, J. W. (1941). Hum. Biol., 13, 139 .

-, Turrell, E. S., Belding, H. S., and Horvath, S. M. (1943), Turrell, E. S., Belding, H.

Taylor, H. L., Henschel, A. F., and Keys, A. (1943). Ibid., 139, 583. Weiner, J. S. (1938). J. industr. Hyg., 20, 389. (1944). Oral Communication to the Physiological Society, quoted by Ladell, W. S. S. (1945), Brit. med. Bull., 3, 175 1946). "Studies in adaptation to hot environments." Thesis, Univ. London.

- and Wyndham, C. (1948). Unpublished observations. -, and van Heyningen, R. (1949). Nature, 164, 351 . 